\title{
Implications of Design, Management and Recession Phase in Drip Irrigation on the Total Distribution Efficiency in Blueberry (Vaccinium corymbosum L.) Crops in Areas with High Slopes in Concordia, Argentina
}

\author{
A. Pannunzio', E. A. Holzapfel'2, P. Texeira Soria'1, F. Bologna ${ }^{3}$ \\ ${ }^{1}$ University of Buenos Aires, Buenos Aires, Argentina \\ ${ }^{2}$ Centro de Recursos Hídricospara la Agricultura y la Minería, Chillán, Chile \\ ${ }^{3}$ Berries del Sol S.A., Colonia Ayuí, Argentina \\ Email:pannunzio@agro.uba.ar, eholzapf@udec.cl, texeira@agro.uba.ar,francobologna2000@yahoo.com
}

Received 5 July 2016; accepted 25 July 2016; published 28 July 2016

Copyright (C) 2016 by authors and Scientific Research Publishing Inc.

This work is licensed under the Creative Commons Attribution International License (CC BY).

http://creativecommons.org/licenses/by/4.0/

(c) (i) Open Access

\section{Abstract}

The increase of human population generates the need to improve the efficiency of food production. A thorough planning is required following the scope of economic and sustainable development, being irrigation a basic tool, however water availability is restricted and it obliges farmers to progress increasing water productivity. Irrigation uses around $70 \%$ of total available fresh water, while irrigation water application efficiency is around $\mathbf{4 0 \%}$. Irrigation systems must follow strong criteria at the design stage to achieve high values of water productivity. Maintenance is indispensable to follow the original functioning level of those systems. At last the daily precise management of systems, following soil water potential, considering the effective rain storage at root depth of the crop and the evolution of daily evapotranspiration, preserving natural resources, are relevant to achieve low values of water footprint of this crop. In an 8 year drip irrigation system, the Uniformity Coefficient of Christiansen (UCC) measured was 95.14\%; the Uniform Coefficient of the Minor Quart (UCMQ) was $\mathbf{9 3 . 1 6 \%}$. The Total Distribution Efficiency (EDT) was $\mathbf{9 5 . 1 3 \%}$ when measurements finished while the irrigation systems is of. When measurements also considered the volume collected during the "recession phase in drip irrigation" and the "volume of water collected during recession phase in drip irrigation" collected at different points, EDT was $95.13 \%$. Moreover it can be seen that when three different typical soil of the area were considered, the EDT was, $\mathbf{9 1 . 8 5 \%}, \mathbf{9 1 . 4 7 \%}$ and $\mathbf{9 0 . 3 0 \%}$ respectively, according with different water storage capacity of each soil. The Total Distribution Efficient is a strong method, to evaluate the design and manage- 
ment of drip irrigation systems, under different design criteria, management practices and maintenance of the systems. Water footprint in a blueberry (Vaccinium corymbosum L.) crop with drip and sprinkler anti-frost system, were measure and values obtained were 846, 310, 223, 212, 172 and 218 liters per kg of fresh fruit in the period 2010-2015. The UCC and the UCMQ reflects properly the irrigation design, while the $E D T$ reflects irrigation design, management and maintenance. Water footprint is at last the strong tool to evaluate design and operation of the irrigation system and crop management.

\section{Keywords}

Recession Phase in Irrigation, Water Management, Drip Irrigation, Irrigation Design Criteria, Drip Irrigation Management, Blueberry Crop, Snow Chaser Variety, Irrigation Uniformity, Water Footprint

\section{Introduction}

Water is vital, multifunctional and scare resource, and these characteristics generate a strong competition among water users. A thorough planning is required following the scope of economic and sustainable development. During the seventies, the deficient management of water resources became relevant and the paradigm of Integrated Management of Hydric Resources [1] was suggested.

The increase of human population generates the need to improve the efficiency of food production. At this point, irrigation is a basic tool, however water availability is restricted and it obliges farmers to progress in water productivity. Irrigation uses near $70 \%$ of total fresh water available and the water application efficiency is around $40 \%$ [2].

The use of indicators is basic to reach sustainability [3] and to improve irrigation water management [4] at the design and managing stage of irrigation systems [2]. The water footprint is a good indicator of efficiency of water used in different processes, and it includes direct and indirect use of water to produce goods or services during a certain period [5].

Water footprint concept was proposed in the XXI century by Hoekstra [6]. This concept divides water use considering its source and contamination associated with productive process. In 1993, Allan introduced virtual water concept, measuring the water contained in each product and the water used during the process [7]. Both concepts answer the requirements of quantification of this water use, however water footprint implies volume of water used and virtual water implies the flow of the water as a net balance of the water of a country. Chapagainand Hoekstra estimated water footprint for several countries for the period between 1997-2001 [8]. Currently water footprint is classified as: 1) Blue water that is related with the water use from superficial and ground water sources [9]; 2) Green water is related with the rain water used by the crop; and 3) Grey water is the contaminated water used during the process [10]. Considering the difficulties of measuring grey water, this water is not thoroughly studied as blue and green waters. The differentiation of three types of water is crucial due to environmental implications, thus requiring several management policies [5].

Several authors have considered water footprint in agriculture. Mekkonen and Hoekstra [11] quantified blue, green and grey water for global production of 126 crops. Ridoutt et al. [12] calculated water footprint for mango. Deuret el al. [14] calculated water footprint for kiwi crop. Herath et al. [13] studied grey water of potato crop in New Zeeland. In 2013, the Instituto de Investigaciones Agropecuarias de Chile edited the book "Determinación de la Huella del Agua y estrategias de manejo de los Recursos Hídricos", for several crops including blueberry crop.

The general values for blueberries water footprint are around 341, 334 and $170 \mathrm{~L} / \mathrm{kg}$ for green, blue and grey footprints, resulting in a total of $845 \mathrm{~L} / \mathrm{kg}$ [15]. These values are consistent with those obtained in Chile between 400 and $800 \mathrm{~L} / \mathrm{kg}$ [16].

As an example of the importance of water footprint as an indicator, the ISO 14.046 Standard quantifies water environmental impacts and the possibilities of reducing its effects. In 2014, the Autoridad del Agua de la Provincia de Buenos Aires incorporated water footprint to establish water cost for Argentina farmers. Water foot- 
prints for agricultural production; have been studied by various authors in Argentina [17] with studies of water footprint in rice production in Entre Ríos [18].

The knowledge of water footprint in blueberry (Vaccinium corymbosum L.) crop is an important issue to plan efficient water use, improving productivity, sustainability and competitiveness of irrigated crops [1], [17]. Blueberry in Argentina is destined to the North Hemisphere markets, taking advantage of commercial window during the period of September to December. To produce in September, early growing varieties are required. These varieties need anti-frost protection system during the winter, because some frost occurs in Concordia area of Argentina while plant sensitivity to low temperature is high. Sprinkler, Micro-sprinkler and Mini-sprinkler solid set systems are used to avoid frost damages during the nights in which temperatures below zero happens.

Two main regions produce more than $80 \%$ of the Argentinean production of blueberries: Concordia region, in Entre Rios province in Northeast and the other in the Northwest area of Argentina, in Tucuman and Salta provinces.

This paper discusses water footprint research in blueberries under drip irrigation in Concordia, Argentina.

\section{Material and Methods}

The trail was developed in a farm located at Colonia Ayuí, Concordia, Entre Ríos, Argentina, with the following coordinates: $31^{\circ} 11^{\prime} 24^{\prime \prime S}, 58^{\circ} 02^{\prime} 54^{\prime \prime} \mathrm{W}$. There is a commercial farm called Berries del Sol S.A., with 30 has of Southern High bush Blueberry varieties (Vaccinium corymbosum, L.). Rainfalls in the area are between 800 and $1700 \mathrm{~mm}$ annually all spread around the year. There are sandy soils in the area over a clay layer. Slopes are around $1.7 \%$, with high erosion risk, when combined with the mentioned rainfall amounts. During winter there are frost events, producing some damages for the early crop varieties, as Snow chaser variety and Emerald. This implies the requirement of frost protection systems. Water for irrigation in this area can be obtained from deep wells, these wells can produce usually $300 \mathrm{~m}^{3} \cdot \mathrm{h}^{-1}$. Some farms also built some dams, with storage capacity to provide water considering the requirements of a sprinkler frost protection system, with a precipitation rate of 3.5 $\mathrm{mm} \cdot \mathrm{h}^{-1}$ or $35 \mathrm{~m}^{3} \cdot \mathrm{h}^{-1}$. Those systems worked in average 10 hours per night and 30 nights during winter and early spring.

The relation between water potential of the soils and water content was determined in laboratory to calculate the irrigation dose in order to keep the expected water potential to maximized yields.

Reference water evapotranspiration, was calculated following Penman-Monteith method using CROPWAT program of Food and Agriculture Organization of the United Nations. Crop coefficient to obtain the evapotranspiration of blueberries was calculated following Holzapfel [19] model, considering shaded area of the crop.

Effective rainfall, was calculated with the Soil and Conservation Service of United States Department of Agriculture method that calculate with accuracy precision the water stored in the root depth according with water monthly evapotranspiration and water storage capacity of the soils in the mentioned rooting depth.

The uniformity of the system was measured with the Uniformity Coefficient of Christiansen [15] and by the Uniform coefficient of the minor quarter.

The global efficiency of the drip irrigation system was calculated applying the Total Distribution Efficiency [20] coefficient.

At last water footprint of blueberries was calculated from 2010 to 2015, taking in account that the first harvest season was 2010, so water was basically used that year for plant growing, while in the following years it was also used for fruit production an also to produce fruit, reason why water footprint values decrease dramatically from 2011 to the current years, beyond the strong management efforts to increase water productivity.

\section{Results and Discussion}

\subsection{Climatic Characterization of Concordia}

The study area is located within $31^{\circ} 11^{\prime} 24^{\prime \prime S}, 58^{\circ} 02^{\prime} 54^{\prime \prime} \mathrm{W}$ at 40 meters above sea level in "Berries del Sol” farm in Colonia Ayuí, Concordia, Entre Ríos province. The Concordia climate is a temperate humid, with medium temperatures between $17^{\circ} \mathrm{C}$ to $20^{\circ} \mathrm{C}$, and rainfall in the area varies from 800 to $1700 \mathrm{~mm} /$ year spread all over the year [8]. These values of rainfall are not enough to meet demands of water use for blueberry crop, considering the sandy soil of the area and the shallow root system of the crop (Table 1). In this region, "El Niño" phenomenon is associated with water excess during November while dry seasons can be expected in the other periods [21]. 


\subsection{Soil Water Potential Characterization and Its Importance to Determine Water Requirements}

Concordia region is just aside the Uruguay River, a river with a flow of $5000 \mathrm{~m}^{3} \cdot \mathrm{s}^{-1}$ limiting with Uruguay country. The west border of Entre Rios province is the Parana river with $15,000 \mathrm{~m}^{3} \cdot \mathrm{s}^{-1}$. Bothe are affluent of the Rio de la Plata river. Sandy soils over strong clay subsoil can be found in some spotted areas, in which blueberry crop is cultivated. Main roots of the crop were found up to $20 \mathrm{~cm}$, where soils texture consisted of: clay $9 \%$, silt $10.5 \%$, sand $80.5 \%$, $\mathrm{pH}$ of $\approx 5$, salinity of $0.3 \mathrm{dS} \cdot \mathrm{m}^{-1}$ and cation exchange capacity (CEC) of $8 \mathrm{meq} / 100 \mathrm{~g}$.

For research on crop production, it is important to know the crop response to different water potentials at which water is retained in the soil, determining the water potential threshold of a crop to maximize yields or increase water productivity.

To determine these values, soil samples from several plots were tested in laboratory. Water content was determined at potentials: Of 10, 20, 33 and $125 \mathrm{kPa}$. With these values and for zero to twenty centimeters depth (root activity zone of blueberries), a curve was constructed at different water potentials for three representative soils of the area (Figure 1).

Table 1. Evapotranspiration with Penman-Monteith method (ETo) and climatic data: Concordia region.

\begin{tabular}{|c|c|c|c|c|c|c|c|}
\hline Month & Min Temp & Max Temp & Humidity & Wind & Sunshine & Radiation & ETo \\
\hline & Celcius & Celcius & $\%$ & $\mathrm{~m} / \mathrm{s}$ & Daily hours & $\mathrm{MJ} / \mathrm{m}^{2} /$ day & $\mathrm{mm} /$ day \\
\hline January & 8.4 & 42.2 & 63 & 3.6 & 8.9 & 24.6 & 8.69 \\
\hline February & 7.0 & 41.6 & 68 & 3.4 & 7.7 & 21.5 & 7.75 \\
\hline March & 4.7 & 39.9 & 72 & 3.2 & 7.7 & 19.0 & 6.71 \\
\hline April & 1.5 & 35.0 & 75 & 3.0 & 6.1 & 13.8 & 4.89 \\
\hline May & -1.3 & 31.8 & 78 & 3.1 & 5.9 & 11.0 & 3.96 \\
\hline June & -5.3 & 29.0 & 80 & 3.2 & 4.6 & 8.6 & 3.42 \\
\hline July & -3.9 & 31.6 & 78 & 3.5 & 5.1 & 9.5 & 4.04 \\
\hline August & 2.2 & 32.4 & 74 & 3.6 & 5.7 & 12.2 & 4.7 \\
\hline September & -3.0 & 34.4 & 78 & 3.8 & 6.5 & 16.1 & 5.92 \\
\hline October & 0.9 & 37.8 & 72 & 3.9 & 7.8 & 20.7 & 7.31 \\
\hline November & 2.3 & 39.0 & 69 & 3.7 & 8.5 & 23.6 & 7.96 \\
\hline December & 5.4 & 41.0 & 64 & 3.6 & 9.3 & 25.6 & 8.61 \\
\hline Average & 1.2 & 36.3 & 72 & 3.5 & 7.0 & 17.2 & 6.16 \\
\hline
\end{tabular}

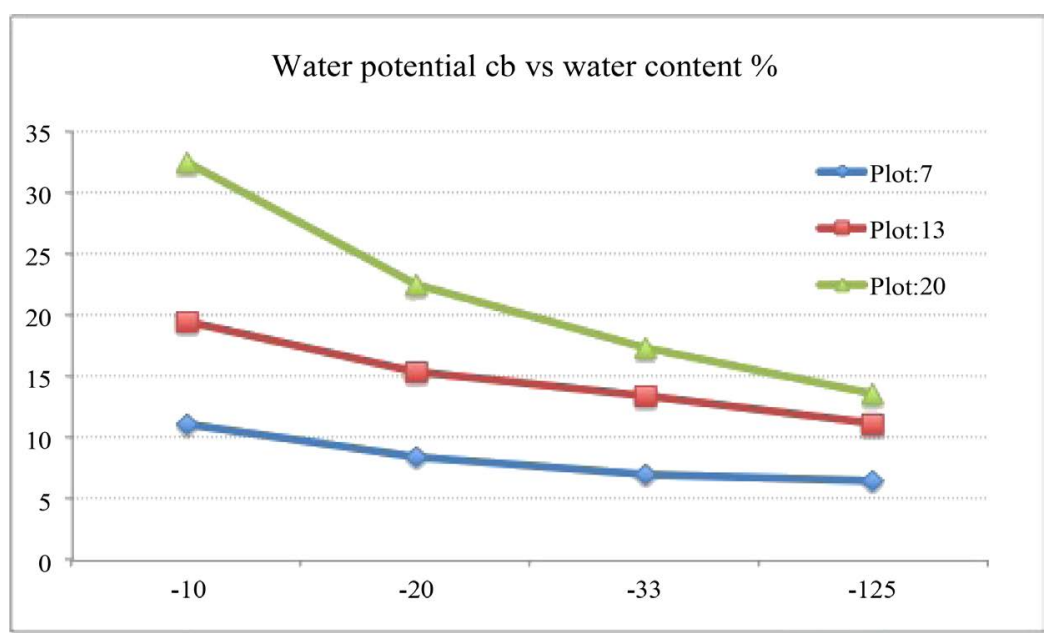

Figure 1. Soil moisture retention curve for two layers soils (Y-axis: \% moisture and X-axis: Tension in cb), for three different plots, for the 0 to $20 \mathrm{~cm}$ layer. 
Blueberry crop is very sensitive to water stress because of superficial root system [9].Around $80 \%$ of the water is extracted from first $20 \mathrm{~cm}$ soil depth with significant root activity, even though roots can extend up to 40 $\mathrm{cm}$. Therefore, crop water requirements at $20 \mathrm{~cm}$ depth were studied in this research. For analyzing the water potential interval for irrigation scheduling, the range of $10-20 \mathrm{kPa}$ was considered [22], because water potential greater than $20 \mathrm{kPa}$ implies decrease in yield [23]. Based on these results, a strict range of water potential must be followed to obtain high yields.

For this range of the water content of those sandy soils, only a small quantity of water should be applied in each irrigation procedure, to maintain the expected water potential, avoiding deep percolation and also water stress. In this farm, plants were spaced at $0.85 \mathrm{~m}$ with row spacing of $3.5 \mathrm{~m}$. The wetted area per plant was observed to be $0.45 \mathrm{~m}^{2}$.plant ${ }^{-1}$, while the drip system is working.

\subsection{Water Requirements for Blueberry Crop in Concordia}

The estimation of water requirements is a key factor to design and operate irrigation system. Evapotranspiration demand of crop was estimated using the Penman-Monteith formula, crop coefficient $(k c)$ and crop coverage factor [11].

The Penman-Monteith includes all parameters that govern energy exchange and corresponding latent heat flux (evapotranspiration, ET) from uniform expanses of vegetation. Most of the parameters are measured or can be readily calculated from weather data. The equation can be utilized for the direct calculation of any crop evapotranspiration as the surface and aerodynamic resistances are crop specific.

$$
E T c=E T o * K c * F c
$$

where, ETo is the reference evapotranspiration, $K c$ is the crop coefficient and $F c$ is the coverage factor depending on the percentage of shaded area of the crop.

ETo is calculated using empirical formulas, Class A pan evaporating, lysimeter measurements. In this study, Penman-Monteith formula was applied using CROPWAT 8.0 with data from Table 1. The effective rainfall is required to know the effective water provided by rainfall, and moisture storage in the root zone depth. One must also consider water percolation and erosion potential. To calculate the effective rainfall, the USDA-Soil Conservation Service method was used. This method considers monthly rainfall and monthly crop evaporation crop (Table 2).

The correct determination of the crop coefficient $(K c)$ is basic to irrigation requirements and to manage irrigation systems scheduling [22]. Several researchers have indicated $K c$ value of blueberry crop between 0.2 - 0.97 for a crop of one to three years old [23], while others indicate $K c$ of 0.2 to 1.1 for the same crop [24]. Number of

Table 2. The effective moisture storage $(\mathrm{mm})$ in the soil in $\mathrm{mm}$.

\begin{tabular}{|c|c|c|c|c|c|c|c|}
\hline & 2010 & 2011 & 2012 & 2013 & 2014 & 2015 & Average \\
\hline January & 31 & 101 & 15 & 31 & 85 & 96 & 58 \\
\hline February & 64 & 100 & 100 & 82 & 100 & 29 & 80 \\
\hline March & 27 & 50 & 60 & 50 & 60 & 14 & 44 \\
\hline April & 32 & 38 & 0 & 26 & 48 & 8 & 29 \\
\hline May & 6 & 20 & 16 & 20 & 20 & 20 & 17 \\
\hline June & 16 & 12 & 0 & 0 & 20 & 20 & 11 \\
\hline July & 12 & 20 & 8 & 14 & 18 & 0 & 15 \\
\hline August & 24 & 18 & 36 & 13 & 6 & 40 & 22 \\
\hline September & 60 & 45 & 0 & 14 & 21 & 40 & 30 \\
\hline October & 0 & 22 & 0 & 29 & 58 & 32 & 24 \\
\hline November & 120 & 9 & 0 & 38 & 85 & 96 & 47 \\
\hline December & 62 & 76 & 121 & 0 & 140 & 48 & 73 \\
\hline Average & 455 & 511 & 356 & 317 & 660 & 442 & 451 \\
\hline
\end{tabular}




\section{A. Pannunzio et al.}

plants per hectare must also be considered [6]. In this study, plants per hectare were 3465. Research studies have shown high crop yield at $100 \%$ of water demand, while applying $150 \%$ of the requirements does not give high yield [25], [26].

\subsection{Timing Options in Drip Irrigation with the Measured Parameters}

Three tables (Tables 3-5) were elaborated considering the upper mentioned parameters, to obtain the number of daily irrigations required to fill water demand of the crop during peak, for blueberry crops under the conditions of Concordia region. Is important to see that three plots in the same farm, requires different timing irrigations intervals, according with the water potential values of each soil. That means that a proper management of the drip irrigation system must operate each type of soil in different way, replacing the exact required volume of water in a different irrigation interval.

Table 3. Irrigation timing for plot number 7.

\begin{tabular}{|c|c|c|}
\hline \multicolumn{3}{|l|}{ Plot number 7: } \\
\hline Peak evapotranpiration & 8 & $\mathrm{~mm} \cdot \mathrm{day}^{-1}$ \\
\hline Wetted area per plant: & 0.45 & $\mathrm{~m}^{2}$ \\
\hline Relevant depth of roots for blueberry crops: & 0.2 & $\mathrm{~m}$ \\
\hline Wetted volume of soil: & 0.09 & $\mathrm{~m}^{3}$ \\
\hline Water content at $10 \mathrm{cb}$ : & 11.2 & $\%$ \\
\hline Water content at $20 \mathrm{cb}$ : & 8.5 & $\%$ \\
\hline Available percentage of water range for that interval: & 2.7 & $\%$ \\
\hline Volume of water to be replaced: & 2.43 & liters·plant $^{-1}$ \\
\hline Flow per hour for 1 liter hour drippers each $30 \mathrm{~cm}$, two drip lines per row: & 6 & 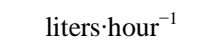 \\
\hline Dally irrigation time to supply water requirements: & 24.3 & minutes \\
\hline Shaded area per plant: & 1.53 & $\mathrm{~m}^{2}$ \\
\hline Daily demand for peak according with shaded area: & 12.24 & liters $\cdot$ plant $^{-1} \cdot$ day $^{-1}$ \\
\hline Minimum operations per day to supply water demand: & 5 & Daily operations \\
\hline
\end{tabular}

Table 4. Irrigation timing for plot number 13.

\begin{tabular}{|c|c|c|}
\hline \multicolumn{3}{|l|}{ Plot number 13: } \\
\hline Peak evapotranpiration & 8 & $\mathrm{~mm} \cdot \mathrm{day}^{-1}$ \\
\hline Wetted area per plant: & 0.45 & $\mathrm{~m}^{2}$ \\
\hline Relevant depth of roots for blueberry crops: & 0.2 & $\mathrm{~m}$ \\
\hline Wetted volume of soil: & 0.09 & $\mathrm{~m}^{3}$ \\
\hline Water content at $10 \mathrm{cb}$ : & 19.5 & $\%$ \\
\hline Water content at $20 \mathrm{cb}$ : & 15.3 & $\%$ \\
\hline Available percentage of water range for that interval: & 4.2 & $\%$ \\
\hline Volume of water to be replaced: & 3.78 & liters·plant $^{-1}$ \\
\hline Flow per hour for 1 liter hour drippers each $30 \mathrm{~cm}$, two drip lines per row: & 6 & liters·hour ${ }^{-1}$ \\
\hline Dally irrigation time to supply water requirements: & 37.8 & minutes \\
\hline Shaded area per plant: & 1.53 & $\mathrm{~m}^{2}$ \\
\hline Daily demand for peak according with shaded area: & 12.24 & liters plant $^{-1} \cdot$ day $^{-1}$ \\
\hline Minimum operations per day to supply water demand: & 3 & Daily operations \\
\hline
\end{tabular}


Table 5. Irrigation timing for plot number 20.

\begin{tabular}{|c|c|c|}
\hline \multicolumn{3}{|l|}{ Plot number 20: } \\
\hline Peak evapotranpiration & 8 & $\mathrm{~mm} \cdot$ day $^{-1}$ \\
\hline Wetted area per plant: & 0.45 & $\mathrm{~m}^{2}$ \\
\hline Relevant depth of roots for blueberry crops: & 0.2 & $\mathrm{~m}$ \\
\hline Wetted volume of soil: & 0.09 & $\mathrm{~m}^{3}$ \\
\hline Water content at $10 \mathrm{cb}$ : & 32.4 & $\%$ \\
\hline Water content at $20 \mathrm{cb}$ : & 22.5 & $\%$ \\
\hline Available percentage of water range for that interval: & 9.9 & $\%$ \\
\hline Volume of water to be replaced: & 8.91 & liters-plant ${ }^{-1}$ \\
\hline Flow per hour for 1 liter hour drippers each $30 \mathrm{~cm}$, two drip lines per row: & 6 & liters hour $^{-1}$ \\
\hline Dally irrigation time to supply water requirements: & 89.1 & minutes \\
\hline Shaded area per plant: & 1.53 & $\mathrm{~m}^{2}$ \\
\hline Daily demand for peak according with shaded area: & 12.24 & liters $\cdot$ plant $^{-1} \cdot$ day $^{-1}$ \\
\hline Minimum operations per day to supply water demand: & 1.3 & Daily operation \\
\hline
\end{tabular}

For plant number seven, 2.43 liters must be filled 5 times per day. For plot number thirteen, 3.78 liters must be filled 3 times per day, and for plot 20 with a wider range of water content for the same water potential range, 8.91 liters must be given 1.3 times per day.

\subsection{Design and Evaluation of Drip Irrigation System}

English et al. [27] mentioned that irrigated agriculture will need to provide two-thirds of the increase in food to feed the growing population. The drip irrigation system was designed considering two laterals of drippers at a dripper spacing of $30 \mathrm{~cm}$ and drippers with 1 liter per hour per emitter. Mini-sprinkler irrigation system is commonly used as anti-frost system in this area as mentioned before. Wells at the site can produce up to $300 \mathrm{~m}^{3} \cdot \mathrm{h}^{-1}$ for anti-frost irrigation purpose. The $\mathrm{pH}$ of the water is 6.5 with electrical conductivity of $0.14 \mathrm{dSm}^{-1}$. The design and operation of the system are relevant to improve water management and the economic profitability of irrigated agriculture [1]. The Uniformity Coefficient of Christiansen [15] is a statistical coefficient to show the dispersion between all values and the average value.

$$
\operatorname{UCC}(\%)=\left[1-\frac{\sum_{i=1}^{n}\left|x_{i}-\bar{x}\right|}{n \bar{x}}\right] \times 100
$$

where, $x_{i}$ is the emitter flow $\left(\mathrm{h} \mathrm{h}^{-1}\right), \bar{x}$ is the average flow of the evaluated emitters $\left(\mathrm{l} \mathrm{h}^{-1}\right)$, and $n$ is the number of emitters.

The UCC coefficient of $95.13 \%$ was obtained for the study areas. The Uniform coefficient of the minor quarter (UCMQ) is given below:

$$
U C M Q=\frac{x_{25}}{x}
$$

where, $x_{x}$ is the average flow of the evaluated emitters; and $x_{25}$ is the average flow emitted by the $25 \%$ of the emitters of the minimum flow.

The UCMQ for the same emitters was $93.69 \%$.

$$
E D T=\left[1-\frac{\sum_{i=1}^{n}\left|x_{i}-X_{r}\right|}{n * X_{r}}\right] \times 100
$$


where, $E D T$ is the total distribution efficiency; $x_{i}$ is the water infiltrated for $i$ point (mm); $X_{r}$ is the crop water need (mm); and $n$ is the number of observations according to Holzapfel model [20].

The total distribution efficiency shows the way in which water distribution is compared with water requirements, as well as the soil water holding capacity in the extracted root zone. This analysis is focused in the variations between water required and water store in the root zone in each point.

The EDT considers all the water irrigated by the systems during the application time plus the water during "the recession phase" concept basically used in surface irrigation, but also very important, in drip systems, in which while following tightly soil water potential, demands several daily irrigation operations, like pulse irrigation. With several irrigations per day, the remaining volume of water during the irrigation phase will be drained of the system, according with hydraulic design, type of drippers, topographic shape of each plot, etc.

The value obtained of EDT, in plots 7, 13 and 20, were: 91.85\%, 91.47\% and 90.30\%. This high efficient values shows that even thought there are very high, there is a strong relation between irrigation efficiency and criteria used during the design and management system, according, with soils, crops, slopes, water quality, etc.

\subsection{Blueberry (Vaccinium corymbosum L.) Yield (VAR. Snowchaser): Concordia, entre Ríos, Argentina}

To quantify water productivity we measure the yield of a Snow chaser blueberry variety, planted in the farm during 2010. The average yields obtained per plant from 2010 to 2015 are shown in Figure 2.

\subsection{Estimation of Water Footprint for Blueberry (Vaccinium corymbosum L.) (Snowchaser VAR.) in Concordia, entre RÍos, Argentina}

Irrigation sustainability in blueberry crops is an important issue [28]. Blue water is the water applied by the drip irrigation system. The green water is the water received by rainfalls and represents effectively storage in the soil volume explored by roots. Grey water is the water used by the minisprinkler frost protection irrigation system. The effective rain was calculated following the procedure of the Soil Conservation Service of the United States Agriculture Department. In the case of the grey water, authors considered the water applied by the sprinkler anti-frost irrigation system. Considering different components of the water footprint and the yield obtained, water footprint for period 2010 to 2015 of Snow chaser variety under Concordia conditions is shown in Figure 3.

\section{Conclusion}

Food requirements for an increasing population encourage agriculture to produce more food, taking in account that rain fed crops are the protagonists of producing additional food. Available land for crops are a limited and agriculture is using around 70\% of available fresh water. So great efforts must be done, to produce food taking care of water productivity, always following sustainable principles. In that way some tools can be used to reach



Figure 2. Blueberry yield: Grams per plant/year. 


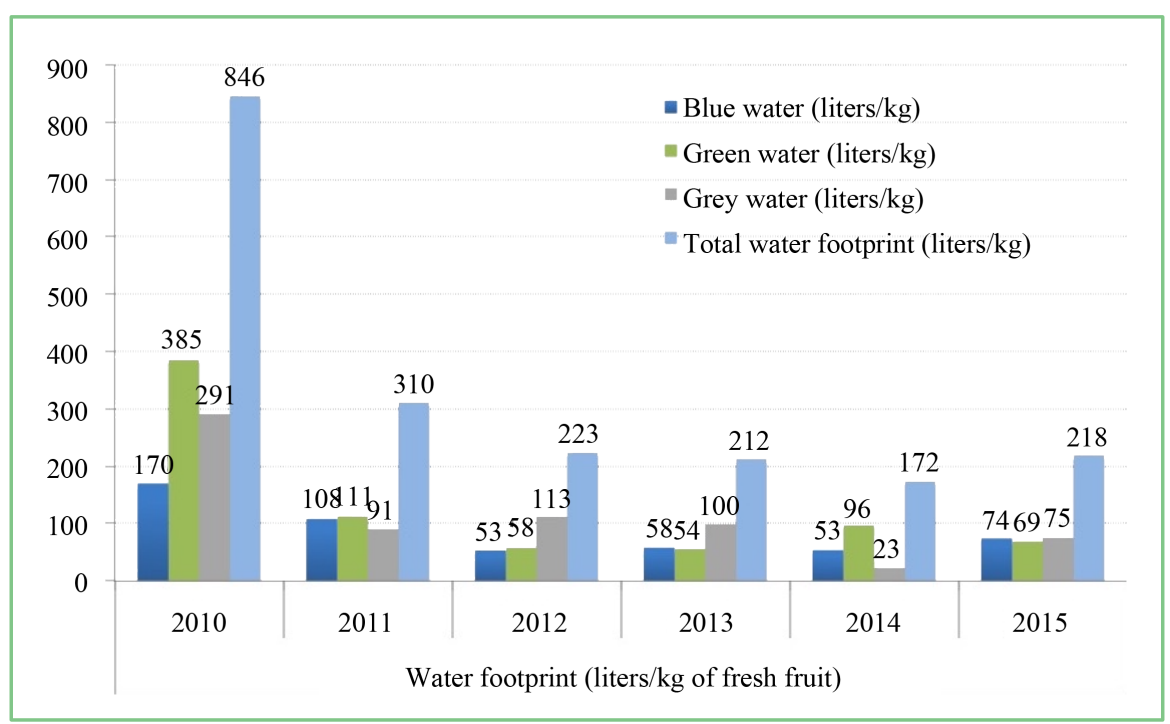

Figure 3. Water footprint: Liters per kg of blue, green and grey water per kg of fruits

the scope. First of all a proper design of irrigation systems is imperative to install efficient irrigation systems. Is essential a daily measure of crop requirements and water potential of the soil in order to determine the exact moment, for each irrigation operation. Management also implies the correct maintenance of drippers, filters, valves and all the components of the system. Farmers can be advised to check their systems using: The Uniformity Coefficient of Christiansen (UCC), the Uniform Coefficient of the Minor Quart (UCMQ) and the Total Distribution Efficiency (EDT). At last water footprint is a great tool to measure water productivity and to compare different systems, and different crops, while water is a scarce resource. Water footprint involves aspects related to the basin, well ruled and legal monitoring of rights and obligations of all social actors; and it can give a fair frame to reach better results for the community without compromising environment. In an 8 year drip irrigation system in a blueberry crop in Concordia, Entre Ríos, Argentina, the Uniformity Coefficient of Christiansen (UCC) measured was 95.14\%, the Uniform Coefficient of the Minor Quart (UCMQ) was 93.16\%. The Total Distribution Efficiency (EDT) was 95.13\% when measurements finished while the irrigation systems is switch of. When measurements also considered the volume collected during the "recession phase in drip irrigation" and the "volume of water collected during recession phase in drip irrigation" collected at different points, EDT was $95.13 \%$. Moreover it can be seen that when three different typical soil of the area were considered, the EDT was, $91.85 \%, 91.47 \%$ and $90.30 \%$ respectively, according with different water storage capacity of each soil. The Total Distribution Efficient is a strong method, to evaluate the design and management of drip irrigation systems, under different design criteria, management practices and maintenance of the systems. Water footprint was measured in a blueberry crop and values obtain were 846, 310, 223, 212, 172 and 218 liters per kg of fresh fruit in the period 2010-2015.

\section{References}

[1] Goyal, M.R., Ed. (2015) Design and Management of Irrigation Systems: Chile. Título del libro: Research Advances in Sustainable Microirrigation, Sustainable Microirrigation, Principles and Practices. International Standard Book Number 13-1-978-77188-016-9 (Hardcover), Apple Academic Press, Toronto, Chapter 8, 147-160.

[2] Hoekstra, A., Chapagain, A., Aldaya, M., Maite, M. and Mesfin, M. (2009) Water Footprint Manual. http://waterfootprint.org/media/downloads/WaterFootprintManual2009.pdf

[3] Altieri, M. and Nicholls, C. (2005) A Rapid, Farmer-Friendly Agro Ecological Method to Estimate Soil Quality and Crop Health in Vineyard Systems. Agroecology and the Search for a Truly Sustainable Agriculture. PNUMA, $277,290$.

[4] Cañas, J., Jiménez, M., Arellano, R. and Moreno-Pérez, M. (2010) Improving Water Application Using Irrigation Indicators (Mejora de la gestión del agua de riego mediante el uso de indicadores de riego). Revista Universidad Nacional de Cuyo, 42, 107-124.

[5] Pannunzio A., Holzapfel, E., Texeira P. and Bologna, F. (2016) Water Footprint in Cultivated Blueberries with Drip Irrigation Systems in Concordia, Argentina. In: Goyal, M.R., Ed., Advances in Irrigation Management of Horticultural 
Crops: An Overview, Apple Academic Press, Toronto, in Press.

[6] Hoekstra, A. and Hung, Q. (2002) Virtual Water Trade: A Quantification of Virtual Waterflows between Nations in a Relation to International Crop Trade. Value of Water Research Report Series 7.

[7] Allan, J. (1998) Watersheds Explaining the Absence of Armed Conflict over Water in the Middle East. MERIAMiddle East Review of International Affairs, 2, 1-3.

[8] Chapagain, A. and Hoekstra, A. (2004) Water Footprints of Nations. In: Value of Water Research. Report Series No. 16. UNESCO-IHE. Delft, the Netherlands. 11, UNEASCO_IHE, Delft, The Netherlands.

[9] Rodríguez Casado, R., Garrido Colmenero, A., Llamas Madurga, M. and Varela Ortega, C. (2008) Hydrological Foot Print of Spanish Agriculture. Reportes de Agua Virtual. Fundación Marcelino Botín.

[10] Falkenmark, M. (2003) Freshwater as Shared between Society and Ecosystems: From Divided Approaches to Integrated Challenges. Philosophical Transactions of the Royal Society of London (Series B, Biological Science), 358, 2037-2049. http://dx.doi.org/10.1098/rstb.2003.1386

[11] Holzapfel, E., Pannunzio, A. and Lorite, I. (2014) Design and Management of Irrigation Systems. In: Goyal, M., Ed., Research Advances in Sustainable Microirrigation Principle and Practices, Volume 1, Apple Academic Press Inc., New Jersey.

[12] Pritchard, R., Haman, D., Smajstrla, A. and Lyrene, P. (1993) Water Use and Irrigation Scheduling of Young Blueberries. Proceedings of the Florida State Horticultural Society, Publication 106, Florida, 147-150.

[13] Herath, I., Clothier, B., Green, S., Horne, D., Singh, R., Marsh, A., Buchanan, A. and Burgess, R. (2012) Measuring the Grey-Water Footprint of Potato Production. http://www.massey.ac.nz/ flrc/workshops/12/Manuscripts/Herath_2012.pdf

[14] Deuret, M., Green, S., Clothier, B. and Mowat, A. (2011) Can Product Water Footprints Indicate the Hydrological Impact of Primary Production?-A Case Study of New Zealand Kiwifruit. Journal of Hydrology, 408, 246-256. http://dx.doi.org/10.1016/j.jhydrol.2011.08.007

[15] Mekkonen, M. and Hoekstra, A. (2010) A Global and High-Resolution Assessment of the Green, Blue and Grey Water Footprint of Wheat. Hydrology and Earth Systems Sciences, 14, 1259-1276. http://dx.doi.org/10.5194/hess-14-1259-2010

[16] Cifuentes, H. and Merino, F. (2013) Hydraulic Footprints to Determine Water Use and to Manage Water Resources. Book Series 50, 210. (Spanish)

[17] Pannunzio, A. and Texeira-Soria, P. (2010) Fertigation Trial in Four Blueberries Varieties in nOrthern Argentina. 28th International Horticultural Congress, Lisboa-Portugal, 22-27 August 2010, 280.

[18] Bryla, D. and Strik, B. (2005) Water Requirements of High Bush Blueberry Planted at Normal and High Densityspacings. HortScience, 40, 1058-1059.

[19] Holzapfel, E.A. (2002) Irrigation in Cranberry. International Congress on Vaccinium corymbosum, Universidad de Concepción, Chillan, Chile.

[20] Holzapfel, E.A. (1984) Selection and Design of Surface Irrigation Methods. PhD Thesis, University of California, Davis.

[21] Heinzenknecht, G. (2005) Impact of “El Niño or La Niña” on Rainfall. Report by Office of Risks and Agriculture, Ministry of Agriculture, Ganadería y Pesca. http://www.ora.gov.ar/informes/enso_precipitaciones.pdf

[22] Haman, R., Pritchard, T., Smajstrla, A., Zazueta, F. and Lyrene, P. (1997) Evapotranspiration and Crop Coefficients for Young Blueberries in Florida. Applied Engineering in Agriculture, 13, 209-216. http://dx.doi.org/10.13031/2013.21601

[23] Pannunzio, A., Vilella, F., Texeira-Soria, P. and Premuzik, Z. (2011) Impact of Irrigation Systems in Blueberries. Revista Brasileira de Engenharia Agrícola e Ambiental, 15, 3-8. http://dx.doi.org/10.1590/S1415-43662011000100001

[24] Bryla, D. and Strik B. (2007) Effects of Cultivar and Plant Spacing on the Seasonal Water Requirements of High Bush Blueberry. HortScience, 132, 270-277.

[25] Bryla, D., Yorgey, B. and Shireman, A. (2009) Irrigation Management Effects on Yield Andfruit Quality of Highbush Blueberry. Acta Horticulturae, 810, 649-656. ttp://dx.doi.org/10.17660/ActaHortic.2009.810.86

[26] Bryla, D. (2008) Water Requirements of Young Blueberry Plants Irrigated by Sprinklers, Microsprays and Drip. Proceedings on Irrigation of Horticultural Crops, ISHS Acta Horticulturae 792, Corvalis, 135-139. http://dx.doi.org/10.17660/actahortic.2008.792.13

[27] English, M.J., Solomon, K.H. and Hoffman, G.J. (2002) A Paradigm Shift in Irrigation Management. Journal of Irrigation and Drainage Engineering, 128, 267-277. http://dx.doi.org/10.1061/(ASCE)0733-9437(2002)128:5(267)

[28] Pannunzio, A. (2010) Efectos de sustentabilidad de los sistemas de riego en arándanos. Orientación, Buenos Aires, 86 p. 


\section{Submit or recommend next manuscript to SCIRP and we will provide best service for you:}

Accepting pre-submission inquiries through Email, Facebook, LinkedIn, Twitter, etc.

A wide selection of journals (inclusive of 9 subjects, more than 200 journals)

Providing 24-hour high-quality service

User-friendly online submission system

Fair and swift peer-review system

Efficient typesetting and proofreading procedure

Display of the result of downloads and visits, as well as the number of cited articles

Maximum dissemination of your research work

Submit your manuscript at: http://papersubmission.scirp.org/ 